\section{Cardiac defect and extracardiac anomalies}

Mikovic Zeljko ${ }^{\mathbf{1}, 2}$

${ }^{1}$ University Clinic for Gynaecology and Obstetrics

"Narodni front", Belgrade, Serbia

${ }^{2}$ University of Belgrade, School of Medicine, Belgrade, Serbia

\section{Abstract}

The overall survival rate in infants affected by congenital heart disease remains low. The poor outcome may be related to the increased association with extracardiac anomalies and aneupoloidy. Since most types of CHD are now amenable to surgery, it is essential that any fetus with congenital structural heart defect should be completely evaluated, noting in particular congenital extracardiac defects which may adversely affect the prognosis. Noncardiac malformations have been reported to occur in up to $50 \%$ of patients with congenital heart disease. The combination of cardiac anomalies with other organ abnormalities appears in genetic syndromes and after exposure to environmental factors. Fetuses with prenatally diagnosed cardiac malformations need to have offer structural abnormalities ruled out. They should be evaluated thoroughly by ultrasound exam, because the detection of an extracardiac anomaly may dramatically affect prognosis. Also, fetuses in which an extracardiac anomaly or chromosome abnormality is diagnosed deserve a complete evolution with full fetal echocardiography. Fetal caryotype analysis should be performed since the risk of aneuploidy approaches $40 \%$ in cases of prenatally diagnosed CHD.

Key words: heart defects, extracardial anomalies

\section{Introduction}

The overall survival rate in infants affected by congenital heart disease (CHD) remains low, ranging from 17 to $24 \%{ }^{1-3}$. The poor outcome may be related to the increased association with extracardiac anomalies and aneupoloidy ${ }^{4}$. Since most types of CHD are now amenable to surgery, it is essential that any fetus with congenital structural heart defect should be completely evaluated, noting in particular

\section{Srcani defekti i ekstrakardijalne anomalije}

Miković Željko ${ }^{\mathbf{1}, 2}$

${ }^{1}$ Univerzitetska klinika za ginekologiju i akušerstvo

"Narodni front", Begrad, Srbija

${ }^{2}$ Univerzitet u Beogradu, Medicinski fakultet, Beograd, Srbija

\section{Apstrakt}

Uopšteno posmatrano, stope preživljavanja dece sa kongenitalnom srčanom bolešću su i dalje nezadovoljavjuće niske. Slabiji ishod može biti povezan sa učestalom udruženošću sa ekstrakardijalnim anomalijama i aneuploidijama. Kako je danas moguće operativno lečiti veliki broj ovih srčanih anomalija, veoma je važno da fetusi kod kojih su one otkrivene budu detaljno dijagnostički evaluirani, naročito u smislu otkrivanja kongenitalnih ekstrakardijalnih anomalija, a s obzirom da njihovo postojanje može negativno uticati na prognozu. Ektrakardijalne malformacije se prema literaturnim podacima javljaju i u do $50 \%$ pacijenata sa urođenim srčanim manama. Kombinacija srčanih sa anomalijama drugih organa najčešće su posledica genetskih sindroma ili izloženosti određenim štetnim uticajima životnog okruženja. Kod fetusa kod kojih je dijagnostifikovana kongenitalna srčana bolest, neophodno je isklučiti postojanje drugih strukturnih anomalija. Oni bi detaljno trebali biti evaluirani ekspertnim ultrazvučnim pregledom, jer dijagnoza koegzistirajućih vansrčanih urođenih anomalija može značajno uticati na prognozu. Naravno, ovo važi i u obrnutom slučaju, kada detekcija ekstrakardijalnih anomalija ili hromozomske abnormalnosti fetusa obavezuje na obavljanje fetalne ehokardiografije. Takođe, ispitivanje fetalnog kariotipa je veoma poželjno u slučaju prenatalnog otkrivanja kongenitalne srčane bolesti, s obzirom da ono nosi rizik aneuploidije u $40 \%$ slučajeva.

Ključne reči: srčani defekti, ekstrakardijalne anomalije

\section{Uvod}

Uopšteno posmatrano, stope preživljavanja dece sa kongenitalnom srčanom bolešću (KSB) su i dalje nezadovoljavjuće niske i kreću se u rasponu od 17 
congenital extracardiac defects which may adversely affect the prognosis 5 . Such an evaluation demands, among the other things, a knowledge of the incidence and clinical significance of extracardiac defects in fetuses with CHD.

Noncardiac malformations have been reported to occur in 25 to $50 \%$ of patients with congenital heart disease $\mathbf{e}^{\mathbf{4}, \mathbf{6 , 7}, \mathbf{8}}$. The combination of cardiac anomalies with other organ abnormalities appears in genetic syndromes and after exposure to environmental factors (teratogenic drugs, infections and systemic maternal diseases) ${ }^{4}$. The spectrum of malformations diagnosed in utero is different from that observed in postnatal series, having the former a more severe prognosis due to the higher association with other structural or chromosomal anomalies, 10,11,12. People involved in the management of affected fetuses should all be aware that most prognostic data in the literature refer to postnatal series, while the prognosis to give parents should be drawn from studies of prenatally detected cases ${ }^{13,14}$.

\section{EXTRACARDIAC ANOMALIES ASSOCIATED WITH HIGH INCIDENCE OF CONGENITAL CARDIAC ANOMALIES}

Musculoskeletal defects are the commonest and accounted for 8,8 to 27 per cent of all extracardiac defects $5, \mathbf{5 , 8}$. The spectrum ranged from single defects like syndactyly to multiple defects as in Holt-Oram, Noonan's and Turner's syndromes. Musculoskeletal defects are followed by gastrointestinal tract anomalies ${ }^{\mathbf{5 , 8}}$.

\section{Gastrointestinal anomalies and wall defects}

Diaphragmatic hernia

In population of fetuses with this condition, 15\% of cases have CHD and $20 \%$ of cases have aneuploidy ${ }^{15,16}$. The most common cardiac anomalies were ventricular septal defect (VSD) and tetralogy of Fallot (ToF). Cardiac anomalies were also reported in association with diaphragmatic hernia as part of chromosomal abnormalities ${ }^{4}$. Although karyotypes play an important role in prenatal diagnosis, they are not predictive of normal cardiac structure when normal in the abnormalities studied. Even when the karyotype is normal in the presence of this abnormality, fetal echocardiography is indicated ${ }^{\mathbf{1 7}}$.

\section{Omphalocele}

do $24 \%{ }^{1-3}$. Slabiji ishod može biti povezan sa učestalom udruženošću sa ekstrakardijalnim anomalijama i aneuploidijama ${ }^{4}$. Kako je danas moguće operativno lečiti veliki broj ovih srčanih anomalija, veoma je važno da fetusi kod kojih su one otkrivene budu detaljno dijagnostički evaluirani, naročito u smislu otkrivanja kongenitalnih ekstrakardijalnih anomalija, jer njihovo prisustvo može negativno uticati na prognozu ${ }^{5}$. Ta evaluacija zahteva znanja o incidenci i kliničkom značaju ekstrakardijalnih defekata $\mathrm{u}$ fetusa sa KSB.

Ektrakardijalne malformacije se prema literaturnim podacima javljaju i u do $50 \%$ pacijenata sa urođenim srčanim manama $\mathbf{4 , 6 , 7 , 8}$. Kombinacija srčanih sa anomalijama drugih organa najčešće su posledica genetskih sindroma ili izloženosti određenim štetnim uticajima životnog okruženja (teratogeni lekovi, infekcije i sistemske bolesti majke) $)^{4}$. Spektrum i učestalost malformacija dijagnostikovanih in utero se razlikuju u odnosu na one posmatrane u postnatalnim serijama. Anomalije otkrivene in utero imaju ozbiljniju prognozu, s obzirom na čestu udruženost sa strukturnim ili hromozomskim anomalijama, 10,11,12. Lekari uključeni u dijagnostiku i tretman ovih fetusa moraju biti svesni da je najveći broj literaturnih podataka vezanih za prognozu dobijen većinom iz postnatalnih serija. Ali u savetovanju budućih roditelja treba predočiti prognostičke procene onih studija koje se odnose na prenatalno otkrivene slučajeve ${ }^{\mathbf{1 3 , 1 4}}$.

\section{EXTRAKARDIJALNE ANOMALIJE POVEZANE SA VISOKOM INCIDENCOM KONGENITALNIH SRČANIH ANOMALIJA}

Muskuloskeletni defekti su najčešće anomalije udružene sa KSB i čine 8,8 do $27 \%$ svih ekstrakardijalnih defekata ${ }^{5,6,8}$. Spektrum ovih anomalija obuhvata izolovane defekate kao što je sindaktilija, pa do multiplih defekata u sklopu sindroma kao što su Holt-Oram, Noonan i Turner. Muskulosketne defekte po učestalosti prate anomalije gastrointestinalnog trakta ${ }^{5,8}$.

Gastrointestinalne anomalije i defekti prednjeg trbušnog zida

Dijafragmalna hernija

U populaciji fetusa sa ovom anomalijom $15 \%$ ima udruženu KSB, dok 20\% ima aneuploidije ${ }^{\mathbf{1 5}, \mathbf{1 6}}$. Najčešće srčane anomalije su ventrikularni septalni defekt (VSD) i tetralogija Fallot (ToF). Srčane 
Omphaloceles may occur in isolation or be associated with chromosomal, other systemic abnormalities or pentalogy of Cantrell (omphalocele, congenital diaphragmatic hernia, sternal defect, pericardial-peritoneal connection and intrinsic heart disease) $)^{\mathbf{1 8}}$. From population of fetuses with omphalocele, $31 \%$ to $58 \%$ of cases have aneuploidy (trisomies 13 and 18 ) and $20 \%$ to $40 \%$ of cases have CHD related to ectomesenteric fold involved ${ }^{17,19}$. The most common CHD in omphalocele fetuses is $\mathrm{ToF}^{19}$. Frequent coexisting cardiac anomalies are atrial septal defect (ASD), VSD and persistent pulmonary hypertension ${ }^{\mathbf{1 8}}$.

\section{Duodenal atresia}

One third of fetuses with duedenal atresia (Figure No and Figure No ) have trisomy 21 and $27 \%$ of them have $\mathrm{CHD}^{17}$.

\section{Central nervous system (CNS) anomalies}

Incidence of CNS malformations in children with CHD varies from $3.2 \%$ to $6.9 \%$. Relationship between the type of CNS anomaly and CHD does not exist, but propensity toward septal defects was noted ${ }^{4}$.

\section{Hydrocephalus}

The association of congenital hydrocephalus and CHD is infrequent, but may present considerable dilemmas in management ${ }^{\mathbf{2 0}}$. Overall, approximately $4.5 \%$ of cases of hydrocephalus diagnosed postnatally and $15 \%$ of cases diagnosed prenatally have CHD. Cardiac anomalies in these cases are predominately VSD and ToF ${ }^{21}$. Hydrocephaly, which may be accompanied by Dandy-Walker malformation, may be associated with a VSD or double outlet right ventricle ${ }^{22}$. Dandy-Walker syndrome is characterized by the association of posterior fossa cyst; defect in the cerebellar vermis, through which the cyst communicates with the fourth ventricle; and a variable degree of hydrocephalus (Figure No ).

\section{Agenesis of corpus callosum}

As a consequence of agenesis of corpus callosum, the two lateral ventricles are set apart with upward displacement of the third ventricle. The sonographic appearance of the defect may be very similar to that of uncomplicated hydrocephaly. The defect is frequently associated with other anomalies of the CNS and other systems, including the cardiovascular. Cardiac anomalije se takođe javljaju udružene sa dijafragmalnom hernijom u sklopu hromozomskih abnormalnosti ${ }^{4}$. Iako kariotip igra veoma važnu ulogu u prenatalnoj dijagnostici, njegov normalan nalaz nije od značajnog prediktivnog značaja normalne srčane strukture. To znači da je u prisustvu dijafragmalne hernije indikovano izvođenje fetalne ehokardiografije, čak i kad je kariotip uredan ${ }^{17}$.

\section{Omfalocela}

Omfalocela se može javiti izolovano ili udružena sa drugim hromozomskim, sistemskim abnormalnostima ili u sklopu Cantrellove pentalogije (omfalocela, kongenitalna dijafragmalna hernija, sternalni defekt, perikardijalno-peritonealne veze i kongenitalna srčana bolest) ${ }^{18}$. U populaciji fetusa sa dijagnostikovanom omfalocelom, $31 \%$ do $58 \%$ slučajeva imaju aneuploidije (trizomija 13 i 18) i u 20\% do 40\% slučajeva imaju KSB povezanu sa ektomezenteričnim naborom ${ }^{17,19}$. Najčešća KSB u fetusa sa omfalocelom je $\mathrm{ToF}^{19}$. Česte koegzistirajuće srčane anomalije su i atrialni septalni defekt (ASD), VSD i perzistentna plućna hipertenzija ${ }^{\mathbf{1 8}}$.

\section{Duodenalna atrezija}

Trećina fetusa sa duedenalnom atrezijom ima trizomiju 21, a $27 \%$ ima $\mathrm{KSB}^{17}$.

\section{Anomalije centralnog nervnog sistema (CNS)}

Incidenca CNS malformacija u dece sa KSB varira od $3.2 \%$ do $6.9 \%$. Povezanost između pojedinih tipova CNS anomalija i KSB ne postoji, ali je zabeležena tendencija ka ispoljavanju septalnih defekata ${ }^{4}$.

\section{Hidrocefalus}

Istovremeno prisustvo urođenog hidrocefalusa i KSB nije često, ali može zadati značajne dileme vezane za tretman ovih pacijenata ${ }^{20}$. Generalno, oko $4.5 \%$ slučajeva hidrocefalusa postnatalno dijagnostikovanih i $15 \%$ prenatalno dijagnostikovanih imaju KSB. Srčane anomalije u ovim slučajevima su predominantno VSD and $\mathrm{ToF}^{21}$. Hidrocefalus, koji može biti praćen Dandy-Walker malformacijom (Slika 1), može biti povezan sa VSD ili double outlet right ventricle (DORV) ${ }^{22}$, što je prikazano na Slici 2. Dandy-Walker sindrom se karakteriše istovremenim prisustvom cistom zadnje lobanjske jame, defektom cerebelarnog vermisa, kroz koji cista komunicira sa četvrtom komorom, kao i različit stepen hidrocefalusa. 
anomalies largely include ToF or double outlet right ventricle ${ }^{23}$.

\section{Genitourinary system anomalies}

In patients with CHD, $13 \%$ have coexisting genitourinary anomalies ${ }^{24}$. The most frequent is hydronephrosis with prevalence of $23 \%$, followed by genital malformation (21\%), renal agenesis $(18 \%)$ and horsehoe kidney (11\%).

\section{GENETIC SYNDROMES \\ ASSOCIATED WITH MAJOR CARDIAC DEFECTS}

\section{Tuberous sclerosis}

Tuberous sclerosis is a single gene autosomal-dominant disorder characterized by multiple hamartoma formations in several tissues, especially brain, skin, heart and kidneys. Fetal cardiac tumors (rhabdomyomas) constitute the main abnormality visuelized by prenatal ultrasound examination (Figure No ). Cerebral lesions, particulary those involving the basal ganglia and periventricular region, are usually smaller and more difficult to detect than cardiac masses, but intracranial signs such as secondary ventriculomegaly may be detected earlier ${ }^{4}$. Skin lesions and cystic bone changes are undetectable prenatally, as well cysts and angiolipoma of kidneys.

\section{Noonan syndrome}

This is an autosomal recessive condition with wide variability in expression. Noonan syndrome is characterised by lymphedema thouth to be due to dysplasia of the lymphatic systen, short stature, short and webbed neck, heart defects, shield chest hyperthelorism and low-set ears ${ }^{\mathbf{2 5}}$. The prenatal ultrasound findings reported in Noonan syndrome include accumulation of nuchal fluid which may disappear or continue into the second trimester (Figure No ), and can occasionally lead to full-blown hydrops and risk of

\section{Ageneza corpus callosuma}

Kao posledica nedostatka corpus callosuma, bočne komore su međusobno odvojene kaudalnom dislokacijom treće moždane komore. Ultrazvučna slika ovog defekta nekad je veoma slična nekomplikovanom hydrocephalusu. Ova anomalija često je povezana sa drugim anomalijama CNS-a i drugih sistema, uključujući kardiovaskularni. Srčane anomalije koje najčešće prate ovu anomaliju su ToF i DORV ${ }^{23}$

Anomalije genitourinarnog sistema

U $13 \%$ fetusa sa KSB prisutne su koegzistirajuće genitourinarne anomalije ${ }^{24}$. Najčešća je hidronefroza sa prevalencom od $23 \%$, a prate je genitalne malformacije $(21 \%)$, renalna ageneza $(18 \%)$ i potkovičasti bubreg $(11 \%)$.

\section{GENETSKI SINDROMI POVEZANI SAKRUPNIM SRČANIM ANOMALIJAMA}

\section{Tuberous sclerosis}

Tuberous sclerosis je autozomno-dominantni poremećaj koji karakteriše prisustvo multiplih hamartoma u više tkiva i organa, naročito u mozgu, koži, srcu i bubregu. Tumori fetalnog srca (rhabdomyomi) čine najčešće anomalije vizuelizovane prenatalnim ultrazvučnim pregledom. Moždane lezije, naročito one koje se nalaze na nivou bazalnih ganglija i periventrikularne regije, obično su malih dimenzija i teže se otkrivaju, ali intrakranijalni znaci kao što je sekundarna ventrikulomegalija mogu ukazati na njihovo postojanje ${ }^{4}$. Kožne lezije i cistične promene na kostima se ne mogu detektovati prenatalno, a to je slučaj i sa cistama i angiolipomima burega.

\section{Noonan sindrom}

Ovo autozomno-recesivno stanje ima širok varijabilitet $\mathrm{u}$ ispoljavanju. Noonan sindrom se karakteriše limfedemima (koje su verovatno posledica displazije 
intrauterine death ${ }^{4}$. Also, femur lengths at or just below the lower end of the normal range, renal anomalies, polyhydramnion, pleural effusions and cystic hygroma have been reported ${ }^{\mathbf{2 6}}$. Cardiac anomalies are present in about $60 \%$ cases and left ventricular hypertrophy with narrowing at the level of aortic semilunar valves (Figure No and No ), pulmonary stenosis, dysplastic pulmonary valve and ASD are the most common.

\section{Smith-Lemli-Opitz syndrome}

This is a common autosomal recessive disorder, with a birth prevalence of about one in $20000^{4}$. This features includes multiple anomalies including typical facial appearance, mental and growth retardation, short limbs, cardiac anomalies, renal hypoplasia, urethral stenosis, cystic renal dysplasia, postaxial polydactyly, syndactyly of the second and third toes, genital and other internal organs abnormalities and deficiency of the enzyme 7-dehydrocholesterol reductase $^{4,27}$. The most common coexistant heart anomialies are VSD, ASD, atriomegaly and ventriculomegaly.

\section{Holt-Oram syndrome, Heart-hand syndrome, type 1}

The familiar transmision of CHD and upper-extremity deformities was first reported by Holt and Oram in 1960. This is a genetically determined disorder in which aplasia or hypoplasia of the digital rays and/or radius are associated with congenital heart disease ${ }^{4}$. Cardiac anomalies are primarily ASD and VSD, sometimes associated with arrythmia. CHDs which may also accomany Holt-Oram syndrom: tricuspid atresia, mitral stenosis, mitral valve prolapse, pulmonic stenosis, hypoplastic pulmonary artery, patent ductus arteriosus, anomalous pulmonary venous return, conduction defects, ToF, aortic arch malformation, coarctation of the aorta, replased subclavian artery, persistent left superior vena cava. The most common skeletal anomalies are absence of the thumb, triphalangeal thumb, pouce flotant, clinodactily, syndactily, radial-ray aplasia, ulnar aplasia, phocomelia, carpal bone anomalies, upper extremity articulation defects. Figure No and figure No.

\section{Thrombocytopenia-absent radius (TAR) syndrome}

This is an autosomal recessive syndrome characterized by radial aplasia and thrombocytopenia. Congenital heart defects, primarily ToF and ASD are occasional findings. The diagnosis of limfatičnog sistema), niskim rastom, širokim vratom, srčanim defektima, hipertelorizmom i nisko postavljenim ušnim školjkama ${ }^{25}$. Karakteristični nalaz na prenatalnom ultrazvučnom pregledu je akumulacija nuhalne tečnosti koja u drugom trimestru trudnoće može nestati ili perzistirati, a ponekad i progredirati u fetalni hidrops koji sa sobom nosi rizik intrauterine smrti ploda ${ }^{4}$. Takođe, dužina butne kosti ploda se često nalazi na donjoj ili ispod donje granice normalnih vrednosti, a ultrazvučno se često otkriju anomalije bubrega, polihidramnion, pleuralne efuzije i cistični higrom ${ }^{26}$. Srčane anomalije su prisutne u oko $60 \%$ slučajeva, a najčešće su hipertrofija leve komore sa suženjem na nivou aortnih semilunarnih zalistaka, pulmonarna stenoza, displastična pulmonarna valvula i ASD.

\section{Smith-Lemli-Opitz sindrom}

Ovo je autozomno-recesivno stanje ima prevalencu od oko 1 na 20000 porođaja $^{4}$. Ono podrazumeva postojanje multiplih anomalija i abnormalnosti, kao što su karakterističan izgled lica, mentalnu retardaciju, zastoj u telesnom rastu, kratke ekstremitete, srčane anomalije, bubrežnu hipoplaziju, uretralnu stenozu, cističnu renalnu displaziju, postaksijalnu polidaktiliju, sindaktiliju drugog i trećeg možnog prsta, abnormalnosti genitalnog i drugih unutrašnjih organa, kao i deficit enzyma 7-dehydrocholesterol reductaze ${ }^{4,27}$. Srčane anomalije koje su najčešće prisutne u sklopu ovog sindroma su VSD, ASD, atriomegalija i ventrikulomegalija.

\section{Holt-Oram sindrom}

Familijarno nasleđivanje KSB i deformiteta gornjih ekstremiteta je prvi put primećeno i notirano od strane Holta i Orama 1960. godine. Ovaj genetski uslovljen poremećaj karakterišu skeletne anomalije, aplazija ili hipoplazija radijusa i $\mathrm{KSB}^{4}$. Srčane anomalije su prvenstveno ASD i VSD, koje su nekad praćene aritmijom. Iako ređe, u Holt-Oram sindromu mogu biti prisutni trikuspidna atrezija, mitralna stenoza, prolaps mitralne valvule, pulmonarna stenoza, hipoplazija pulmonarne arterije, patentni duktus arteriozus, ToF, malformacije aortnog luka, koarktacija aorte, perzistentna leva gornja šuplja vena. Najčešće skeletne anomalije su odsustvo palca, trifalangealni palac, klinodaktilija, sindaktilija, ulnarna aplazija, fokomelija, anomalije karpalne kosti, defekti zglobova gornjih ekstremiteta. 
thrombocytopenia can be confirmed prenatally by umbilical blood sampling ${ }^{28}$.

\section{VATER association}

This stands for: V- vertebral defects, A- anal atresia, C- cardiac anomalies, T- tracheoesophageal fistula with E- esophageal atresia, R- renal and radial dysplasia, L- limb defect). Patients are considered to have VACTERL association when 3 or more organ systems are involved. The most ferquent defects described are tracheoesophageal fistula and anal or vertebral anomalies ${ }^{4}$. The diagnosis can also be suspected because of polyhydramnios in the presence of a small or absent fetal stomach (the tracheoesophageal fistula), hemivertebrae or scoliosis, or limb (in particular radius anomalies, club hand, reduction defects and polydactylies), renal and cardiac defects (Figure No ).

\section{Meckel-Gruber syndrome}

This is lethal, autosomal recessive syndrome characterized by posterior encephalocele, postaxial polydactyly and cystic kidneys ${ }^{4}$. Other abnormalities detectable by ultrasound are microcephaly, Dandy-Walker abnormaliti-

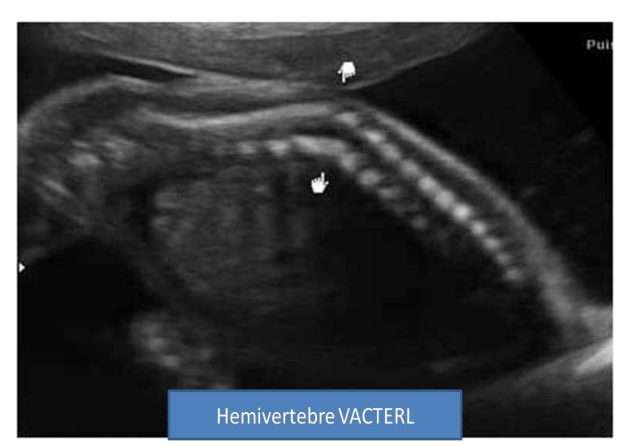

Slika 3. Ultrazvučni prikaz hemivertebre u sklopu VACTERL Syndroma

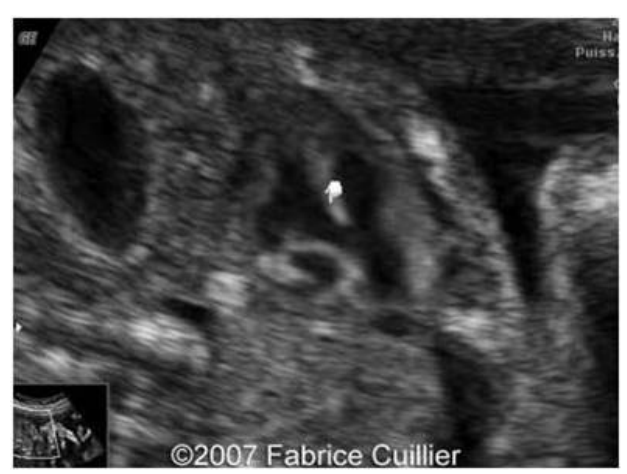

Slika 4. Srčana mana u sklopu VACTERL Syndroma es, Arnold-Chiari malformation, microphtalmia, micrognathia, cleft palate and heart defects ${ }^{29}$. Figure No and figure No.......

\section{CONCLUSIONS}

A careful, systematic search for cardiac anomalies is indicated whenever an extracardiac anomalies is identified. Some anomalies listed above deserve special attention, and thorough echocardiography is mandatory because of the frequent association with cardiac anomlies ${ }^{4}$. A major impact of antenatal diagnosis of malformations is related to the

\section{Trombocitopenija-odsutni radius sindrom}

Ovaj sindrom se nasleđuje autozomno-recesivno. Karakteriše ga aplazija radiusa i trombocitopenija. Kongenitalne srčane anomalije, prvenstveno ToF i ASD su povremeno prisutne u sklopu obog sindroma. Dijagnoza trombocitopenije može se prenatalno potvrditi analizom uzorka fetalne krvi dobijenog kordocentezom $^{28}$.

VACTERL asocijacija

Naziv ovog stanja je akronim koji označava: V- vertebralne defekte, Aanalnu atreziju, C- srčane (cardiac) anomalije, T- traheoezofagealnu fistulu sa Eezofagealnom atrezijom, Rrenalna i radijalna displazija, L- (limb) defekti ekstremiteta. Da bi postavili dijagnozu VACTERL asocijacije potrebno je da su anomalije prisutne na najmanje 3 organa ili organska sistema. Najčešće su prisutni traheoezofagealna fistula, anomalije anusa ili kičmenog stuba $^{4}$, što je prikazano na slici 3. Sumnju na ovo stanje može podići polihidramnion u prisustvu odsustva ili veoma malog fetalnog želudca (traheoezofagealna fistula), hemivertebre ili skolioze, ili defekata ekstremiteta (naročito anomalije radijusa, club hand, redukcioni defekti i polidaktilija), bub-

rega i srca (slika 4).

\section{Meckel-Gruber sindrom}

Ovaj letalni sindrom se autozomalno-recesivno nasleđuje. Karakterišu ga zadnja encefalocela, postaksijalna polidaktilija i cistični bubrezi ${ }^{4}$. Druge abnormalnosti koje se prenatalno ultrazvučno mogu otkriti su mikrocefalija, Dandy-Walker anomalija, Arnold-Chiari malformacija, mikroftalmija, mikrognatija, rascep nepca i srčani defekti29. 
severity of malformations detected. Most severe defects are reportedly detected earlier than minor ones, which is especially relevant in many countries where only before viability is termination of pregnancy authorized by law $^{\mathbf{3 0}}$. The gestational age at which a severe malformation is diagnosed is therefore crucial to further management of the pregnancy.

Fetuses with prenatally diagnosed cardiac malformations need to have offer structural abnormalities ruled out. They should be evaluated thoroughly by ultrasound exam, because the detection of an extracardiac anomaly may dramatically affect prognosis. Also, fetuses in which an extracardiac anomaly or chromosome abnormality is diagnosed deserve a complete evolution with full fetal echocardiography. Fetal caryotype analysis should be performed since the risk of aneuploidy approaches $40 \%$ in cases of prenatally diagnosed CHD.

\section{ZAKLJUČAK}

Pažljivo sistematsko traženje srčanih anomalija je indikovano uvek kada se otkriju ekstrakardijalne anomalije. Neke od njih su naročito važne i zahtevaju obavljanje minucioznog fetalnog ehokardiografskog pregleda jer su često udružene sa anomlijama srca ${ }^{4}$. Značaj antenatalno postavljene dijagnoze je povezan sa ozbiljnošću otkrivene malformacije. Teške anomalije se češće otkriju ranije u trudnoći u odnosu na one sa boljom prognozom, što je od velikog značaja u onim zemljama u kojima postoje zakonske restrikcije u vezi gestacione starosti u kojoj se prekid trudnoće može obaviti iz medicinskih indikacija $^{30}$. Zato je gestaciona starost $\mathrm{u}$ kojoj se otkriju teške malformacije od krucijalnog značaja za dalje vođenje takve trudnoće.

Fetusi sa KSB moraju biti detaljno evaluirani da bi se isključilo postojanje drugih strukturnih abnormalnosti. To podrazumeva detaljan ultrazvučni pregled svih organa i organskih sistema, jer detekcija ekstrakardijalnih anomalija može dramatično uticati na prognozu. Takođe i svi fetusi sa ekstrakardijanim anomalijama ili hromozomskim abnormalnostima zahtevaju obavljanje detaljne fetalne ehokardiografije. Analiza kariotipa je imperativ u fetusa sa prenatalnno dijagnostikovanom KSB, jer je oni imaju skoro $40 \%$ rizika postojanja aneuploidija.

\section{REFERENCES}

1. Whiteman VE, Reece EA. Prenatal diagnosis of major congenital malformations. Curr Opin Obstet Gynecol 1994; 6: 459-467.

2. Ferrazi E, Fesslova V, Belloti M et al. Prenatal diagnosis and management of congenital heart disease. J Reprod Med 1989; 34: 207-215.

3. Crawford DC, Chita SK, Allan LD. Prenatal detection of congenital heart disease: factors affecting obstetric management and survival. Am J Obstet Gynecol 1988; 159: 352-356.

4. Degani S. Associated anomalies in congenital heart disease. In: Yagel. S, Silverman NH, Gembruch U. Fetal Cardiology 2003, Martin Dunitz, an imprint of the Taylor and Francis Group, pp. 423-435.

5. Jaiyesimi F, Antia AU. Extracardiac defects in children with congenital heart disease. British Heart Journal, 1979, $42,475-479$.

6. Greenwood RD. Cardiovascular malformations associated with extracardiac anomalies and malformation syndromes. Clin Pediatr 1984; 23 (3): 145-51.

7. Gallo P, Nardi F, Marinozzi V. Congenital extracardial malformations accompanying congenital heart disease. G Ital Cardiol. 1976: 6 (3): 450-9.

8. Wallgren EI, Landtman B, Rapola J. Extracardiac malformations associated with congenital heart disease. Eur J Cardiol. 1978; 7 (1): 15-24.

9. Song MS, Dyhamenahali AH, Chitayat D, Winsor EJT, Ryan G, Smallhorn J, Barrett J, Yoo SJ, Hornberger LK. Extracardiac lesions and chromosomal abnormalities associated with major fetal heart defects: comparison of intrauterine, postnatal and postmortem diagnoses. Ultrasound Obstet Gynecol 2009; 33: 552-559. 
10. Fesslova V, Nava S, Villa L, Fetal Cardiology Study Group of the Italian Society of Pediatric Cardiology. Evaluation and long term outcome in cases with fetal diagnosis of congenital heart disease: Italian multicentre study. Heart 1999; 82: 594-549.

11. Paladini D, Calabro R, Palmieri S, D’Andrea T. Prenatal diagnosis of congenital heart disease and fetal caryotyping. Obstet Gynecol 1993; 81: 679-682.

12. Yates R. Fetal cardiac abnormalities and their association with aneuploidy. Prenat Diagn 1999; 19: $563-566$.

13. Todros T, Capuzzo E, Gaglioti P. Prenatal diagnosis of congenital anomalies. Images Paediatr Cardiol 2001; 7: 3-18.

14. Kern JH, Hayes CJ, Michler RE, Gersony WM, Quaegebeur JM. Survival and risk factor analysis for the Norwood procedure for hypoplastic left heart syndrome. Am J Cardiol 1997; 80: 170-174.

15. Greenwod RD, Rosenthal A, Nadas AS. Cardiovascular abnormalities associated with congenital diaphragmatic hernia. Pediatrics 1976; 57: 92-97.

16. Thorpe-Beeston JG, Gosden CM, Nicolaides KH. Prenatal Diagnosis of Congenital Diaphragmatic Hernia: Associated Malformations and Chromosomal Defects. Fetal Therapy 1989;4:21-28 (DOI: 10.1159/000263386)

17. Fogel M, Copel JA, Cullen MT, Hobbins JC, Kleinman CS. Congenital heart disease and fetal thoracoabdominal anomalies: an associations in utero and the importance of cytogenetic analysis. Am J Perinatol. 1991 Nov; 8 (6): $411-6$.

18. Gibbin C, Touch S, Broth RE, Berghella V. Abdominal wall defects and congenital heart disease. Ultrasound Obstet Gynecol. 2003 Apr; 21 (4): 334-7.

19. Crawford DC, Chapman MG, Allan LD. Echocardiography in the investigation of anterior abdominal wall defects in the fetus. Br J Obstet Gynaecol 1985; 92: 1034-1036.

20. Crawford TS, Olivero WC, Hanigan WC. The prognosis of Children with Hydrocephalus and Congenital Heart Disease. Pediatric Neurosurgery 2000; 33: 12-15.

21. Nyberg AD, Mack LA, Hirsch J et al. Fetal hydrocephalus: sonographic detection and clinical significance of associated anomalies. Radiology 1987 1987; 163:187-191.

22. Olson GK, Halpe DC, Kaplan AM et al. Dandy-Walker malformation and associated cardiac anomalies. Childs Brain 1981; 8: 173-180.

23. Pilu G, Sandri F, Perolo A, et al. Sonography of fetal agenesis of corpus callosum: A survey of 35 cases. Ultrasound Obstet Gynecol 1993; 3: 318-329.

24. Copel JA, Pilu G, Kleinman CS. Congenital heart disease and extracardiac anomalies: associations and indications for fetal echocardiography. Am J Obstet Gynecol. 1986 May; 154 (5): 1121-32.

25. Noonan JA. Hyperthelorism with Turner phenotype. A new syndrome with associated congenital heart disease. Am J Dis Child 1968; 116: 373-80.

26. Benacerraf BR, Green MF, Holmes LB. The prenatal sonographic features of Noonan's syndrome. J Ultrasound Med 1989; 8: 59-63.

27. Irons M, Elias ER, Tint GS et al. Abnormal cholesterol metabolism in the Smith-Lemli-Opitz syndrome: report of clinical and biochemical findings in four patients and treatment in one patient. Am J Med Genet 1994; 50: $347-352$.

28. Boute O, Depret-Mosser S, Vinatir D et al. Prenatal diagnosis of thrombocytopenia- absent radius syndrome. Fetal Diagn Ther 1996; 11: 224-230.

29. Nyberg DA, Hallesy D, Mahony BS et al. Meckel-Gruber syndrome: importance of prenatal diagnosis. J Ultrasound Med 1990; 9: 691-696.

30. Grandjean H, Larroque D, Levi S, Eurofetus Study Group. The performance of routine ultrasonographic screening of pregnancies in the Eurofetus Study. Am J Obstet Gynecol 1999; 181: 446-454.

Autor za korespondenciju: Prof. Dr sci.med. Željko Miković e-mail: zmikovic@hotmail.com 